\title{
Productivity and nutritive quality of dallisgrass (Paspalum dilatatum) as influenced by cutting height and rate of fertilization with poultry litter or commercial fertilizer
}

\author{
Elias J. Bungenstab ${ }^{1^{*}}$, Adolfo C. Pereira Jr. ${ }^{2}$, John C. Lin ${ }^{3}$, James L. Holliman $^{3}$, \\ Russell B. Muntifering ${ }^{3}$ \\ ${ }^{1}$ Van Beek Nutrition, Pocatello, USA; *Corresponding Author: elias@bungenstab.com.br \\ ${ }^{2}$ Elanco Animal Health, Greenfield, USA \\ ${ }^{3}$ Department of Animal Sciences, Auburn University, Auburn, USA
}

Received 30 June 2013; revised 30 July 2013; accepted 15 August 2013

Copyright (C) 2013 Elias J. Bungenstab et al. This is an open access article distributed under the Creative Commons Attribution License, which permits unrestricted use, distribution, and reproduction in any medium, provided the original work is properly cited.

\begin{abstract}
Dallisgrass (Paspalum dilatatum) is well adapted to the Black Belt region of the southeastern US, and information on its productivity and nutritive quality as influenced by fertility is needed. In each yr of a 2-yr study, an existing dallisgrass pasture that had been subdivided into 48 plots of $9.3 \mathrm{~m}^{2}$ each was fertilized with the equivalent of $34(34 \mathrm{~N}), 67(67 \mathrm{~N}), 101(101 \mathrm{~N})$ or $134(134 \mathrm{~N}) \mathrm{kg}$ N/ha from poultry litter (PL) or commercial fertilizer (CF; $\mathrm{NH}_{4} \mathrm{NO}_{3}$ ). In both years, primarygrowth and vegetative regrowth forage was harvested in mid-August and late September, respectively, and forage from each harvest was clipped to either a 5- or $10-\mathrm{cm}$ stubble height. Forage cut to a $5-\mathrm{cm}$ height yielded $71 \%$ more $(P$ $<0.001)$ DM than forage cut to a $10-\mathrm{cm}$ height, but forage dry matter (DM) yields were not different between CF and PL treatments across years and fertilization rates. Concentration of crude protein $(C P)$ was greater $(P=0.002)$ for $C F$ than PL forage and increased for both fertilizer sources with increasing rates of $\mathrm{N}$ application. Forage concentrations of cell-wall constituents were not different between $\mathrm{CF}$ and PL treatments. Forage amended with CF had a higher concentration of $\mathrm{Ca}, \mathrm{Mg}$ and $\mathrm{Mn}$ than PL-amended forage; however, forage amended with PL had a higher concentration of $P$ and $K$ than $C F-a m e n d e d$ forage. There was no effect of fertilizer source on forage concentration of $\mathrm{Al}, \mathrm{Cu}$ or Zn. Results indicate that PL and CF were
\end{abstract}

comparable for supporting productivity and nutritive quality of dallisgrass on Black Belt soils.

Keywords: Dallisgrass; Productivity; Nutritive Quality; Poultry Litter

\section{INTRODUCTION}

Dallisgrass, Paspalum dilatatum, is a warm-season perennial grass indigenous to South America, primarily Uruguay, Argentina and southern Brazil [1]. According to Chase [2], it was first reported in the USA in 1840, collected in Louisiana, and named for Abner T. Dallis of La Grange, GA [3]. Dallisgrass represents just $10 \%$ of the perennial warm-season grassland acreage in the State of Alabama, where its major uses are for pasture, hay and silage [4]. It responds well to fertilization with $\mathrm{N}$ up to $134 \mathrm{~kg} / \mathrm{ha}$, and optimally to $\mathrm{P}$ and $\mathrm{K}$ based on soil test. Furthermore, dallisgrass tolerates frequent defoliation better and maintains its forage quality longer into the growing season than many other commonly utilized perennial $\mathrm{C}_{4}$ grasses $[5,6]$.

The influence of sward height on ingestive behavior and intake of dallisgrass by cattle has been documented in a number of studies [7-10]. Less extensively studied is the resilience of dallisgrass to forage and grazing-animal management practices that result in low stubble heights and significantly reduced photosynthetic leaf area and carbohydrate reserves for production of vegetative regrowth.

Productivity of pastureland in response to fertilization can be expected to differ for different fertilizer sources, soil types, forage species and meteorological conditions. 
In the case of poultry litter, there is currently a very limited body of systems-level knowledge that producers can use in management decisions, litter application rate adjustments, and prescription techniques for controlling and maximizing nutrient-use efficiency in forage-based beef cattle production systems. In the Black Belt region of Alabama, depressed agricultural economies stem in part from oftentimes poor soil fertility in pasture, hayfields and row crops. Economical transportation of poultry litter could enable export of litter from areas of intensive poultry production to the Black Belt region for use as a cost-effective alternative to commercial fertilizer on pasturelands. For these reasons, we conducted a fieldplot study to determine the primary productivity and nutritive quality of dallisgrass as influenced by rates of fertilization with poultry litter or commercial fertilizer.

\section{MATERIALS AND METHODS}

\subsection{Site Characteristics}

The experimental site was an existing dallisgrass pasture located at the Black Belt Research and Extension Center in Marion Junction, AL (32.5 lat., 87.2 ${ }^{\circ}$ long., 61 $\mathrm{m}$ elev.). The pasture had been utilized for grazing prior to 1990 , and since 1990 it has been utilized for hay production. In 2001 to 2004, the pasture was over-seeded in the fall with oats and received $67 \mathrm{~kg}$ of $\mathrm{N} / \mathrm{ha}$ in the spring and early summer of each yr prior to the experiment. The soil beneath the pasture is a clayey loam with a mean $\mathrm{pH}$ of 7.9. Mean annual temperature at the site is $17.6^{\circ} \mathrm{C}$, and mean annual precipitation is $1400 \mathrm{~mm}$. Precipitation and temperature were recorded daily throughout the experiment.

\subsection{Treatments}

Forage in the pasture was clipped to a height of $10 \mathrm{~cm}$ on July 17,2006 , and the study area was subdivided into 48 plots of $9.3 \mathrm{~m}^{2}$ each $(1.5 \mathrm{~m} \times 6.1 \mathrm{~m})$. Each plot received the equivalent of $34(34 \mathrm{~N}), 67(67 \mathrm{~N}), 101(101 \mathrm{~N})$ or $134(134 \mathrm{~N}) \mathrm{kg} \mathrm{N} /$ ha from either poultry litter (PL; $2.75 \% \mathrm{~N}$, air-dry basis) or commercial fertilizer ( $\mathrm{CF}$; $35 \% \mathrm{~N}$ as $\mathrm{NH}_{4} \mathrm{NO}_{3}$ ). Commercial fertilizer was applied to half of the plots utilizing a tractor and spreader, and PL was applied manually to the remaining half of the plots. The PL consisted of wood shavings and manure collected from chicken houses in North Alabama. Prior to transport to the research site, PL was ground to pass a 5-mm screen in a hammer mill and stored in a sealed container under refrigeration. In order to facilitate its transportation to the research site and application to field plots, PL was pre-weighed into paper bags in quantities of $1.14,2.27,3.41$ and $4.54 \mathrm{~kg}$ that corresponded to 1222 $(34 \mathrm{~N}), 2443(67 \mathrm{~N}), 3665(101 \mathrm{~N})$, and $4887(134 \mathrm{~N}) \mathrm{kg}$ poultry litter/ha, respectively.
Half of the plots within each fertilizer source $\times$ application-rate treatment $(n=3)$ were assigned to aboveground clipping heights of either 5 or $10 \mathrm{~cm}$ that simulated different intensities of grazing management. In order to minimize the influence of environmental conditions external to the study area, 12 border plots were maintained around the experimental plots. Border plots received $34 \mathrm{~N}$ from $\mathrm{CF}$ and were clipped to the same height as the study plots to which they were contiguous.

\subsection{Forage Harvesting, Sampling and Laboratory Analyses}

Forage was clipped with a flail-chopping mower when it achieved a mean target height of $20 \mathrm{~cm}$ on August 21, and then again on September 25. Harvested forage was collected into plastic baskets and immediately weighed on a portable field scale. Samples of forage from each plot were placed into tared paper bags, weighed, dried at $55^{\circ} \mathrm{C}$ for $72 \mathrm{hr}$ and ground to pass a $1-\mathrm{mm}$ screen in a Wiley mill. Forage concentrations of crude protein $(\mathrm{CP}=$ $\mathrm{N} \times 6.25)$ and dry matter (DM) were determined according to procedures of AOAC [11], and concentrations of neutral detergent fiber (NDF), acid detergent fiber (ADF) and acid detergent lignin (ADL) were determined sequentially according to the procedures of Van Soest et al. [12]. Concentrations of $\mathrm{P}, \mathrm{K}, \mathrm{Ca}, \mathrm{Mg}, \mathrm{Al}, \mathrm{Cu}, \mathrm{Fe}, \mathrm{Mn}$ and $\mathrm{Zn}$ were measured using inductively coupled argon plasma (ICAP) spectroscopy according to the procedures of Olsen and Sommers [13].

The experiment was repeated in 2007, at which time forage in each plot was clipped to a height of $10 \mathrm{~cm}$ on April 23, amended with the same fertilization treatments as those applied in 2006, and harvested on August 16 and then again on September 27 at the same clipping heights as those assigned in 2006.

\subsection{Statistical Analyses}

Data were analyzed by analysis of variance for a completely randomized design with a $2 \times 2 \times 4$ factorial arrangement of treatments (3 replicates/treatment) in which harvest was treated as a repeated measure using the PROC MIXED procedures of SAS and standard leastsquares model fit [14]. Components of the statistical model included clipping height, fertilizer source, fertilizer application rate and their two- and three-way interactions treated as fixed effects, and year treated as a random effect. Plot was considered the experimental unit. All data are reported as least squares means $\pm \mathrm{SE}$, and the significance level was preset at $P<0.10$ for all analyses.

\section{RESULTS}

\subsection{Temperature and Precipitation}

Monthly mean air temperatures (Table 1) approxi- 
mated or were slightly higher than 30-yr averages for Marion Junction, AL in July, August and September of 2006 and 2007 , but monthly total precipitation was $42 \%$, $69 \%$ and $26 \%$ of average for July, August and September, respectively, in 2006, and was $55 \%, 75 \%$ and $67 \%$ of average, respectively, for the these three months in 2007.

\subsection{Dry Matter Yield}

Forage cut to a $5-\mathrm{cm}$ height yielded $71 \%$ more $(P<$ $0.001)$ DM than forage cut to a $10-\mathrm{cm}$ height (Table 2). There was no difference in DM yield between fertilizer-source treatments; however, the $134 \mathrm{~N}$ treatment yielded one-third more DM than the $34 \mathrm{~N}(P=0.015)$ and $67 \mathrm{~N}(P=0.012)$ treatments.

\subsection{Crude Protein}

There was no difference $(P=0.71)$ in forage concen-

Table 1. Monthly mean air temperatures for 2006 and 2007, and 30-yr averages at Marion Junction, AL.

\begin{tabular}{ccccccc}
\hline \multirow{2}{*}{ Month } & \multicolumn{3}{c}{ Mean, ${ }^{\circ} \mathbf{C}$} & \multicolumn{3}{c}{ Avg. Precipitation, mm } \\
\cline { 2 - 7 } & $\mathbf{2 0 0 6}$ & $\mathbf{2 0 0 7}$ & $\mathbf{3 0 - y r}$ & $\mathbf{2 0 0 6}$ & $\mathbf{2 0 0 7}$ & $\mathbf{3 0 - y r}$ \\
\hline Jan & 11 & 8 & 7 & 105 & 93 & 149 \\
Feb & 8 & 7 & 9 & 136 & 54 & 119 \\
Mar & 14 & 16 & 13 & 60 & 39 & 163 \\
Apr & 21 & 16 & 17 & 23 & 34 & 123 \\
May & 22 & 23 & 22 & 90 & 3 & 104 \\
Jun & 26 & 27 & 26 & 28 & 101 & 113 \\
Jul & $\mathbf{2 9}$ & $\mathbf{2 7}$ & $\mathbf{2 7}$ & $\mathbf{5 4}$ & $\mathbf{7 0}$ & $\mathbf{1 2 9}$ \\
Aug & $\mathbf{2 9}$ & $\mathbf{3 0}$ & $\mathbf{2 7}$ & $\mathbf{5 8}$ & $\mathbf{6 4}$ & $\mathbf{8 5}$ \\
Sep & $\mathbf{2 4}$ & $\mathbf{2 5}$ & $\mathbf{2 4}$ & $\mathbf{2 6}$ & $\mathbf{6 7}$ & $\mathbf{1 0 0}$ \\
Oct & 18 & 20 & 18 & 85 & 66 & 75 \\
Nov & 12 & 12 & 13 & 173 & 39 & 111 \\
Dec & 9 & 11 & 8 & 124 & 58 & 128 \\
\hline
\end{tabular}

Table 2. Forage DM yield (kg/ha) from dallisgrass amended with commercial fertilizer (CF) or poultry litter (PL) at 4 rates of $\mathrm{N}$ application and clipped to a 5- or 10-cm height.

\begin{tabular}{ccccccc}
\hline Clipping height & \multicolumn{2}{c}{$5 \mathrm{~cm}$} & \multicolumn{2}{c}{$10 \mathrm{~cm}$} & \multirow{2}{*}{ Mean } \\
\cline { 1 - 4 } N application rate, kg/ha & CF & PL & CF & PL & \\
\hline 34 & 934 & 785 & 450 & 386 & $640^{\mathrm{a}}$ \\
67 & 846 & 804 & 452 & 408 & $627^{\mathrm{a}}$ \\
101 & 907 & 898 & 639 & 491 & $734^{\mathrm{ab}}$ \\
134 & 957 & 1,031 & 682 & 676 & $836^{\mathrm{b}}$ \\
Mean & 911 & 879 & 556 & 490 & \\
Clipping-height mean & \multicolumn{3}{c}{$895^{\mathrm{c}}$} & \multicolumn{3}{c}{$523^{\mathrm{d}}$} \\
\cline { 1 - 3 }
\end{tabular}

$\overline{a, b}$ Within a column, means without a common superscript differ $(P=0.04$; $\mathrm{SEM}=126 ; \mathrm{n}=48){ }^{\mathrm{c}, \mathrm{d}}$ Within a row, means without a common superscript differ $(P<0.001$; SEM $=119 ; \mathrm{n}=96)$. tration of CP between clipping-height treatments (Table 3). However, forage amended with $\mathrm{CF}$ had 0.8 percentage unit higher $(P=0.002)$ concentration of $C P$ than PL-amended forage. Forage receiving $134 \mathrm{~N}$ had 1.2 and 0.8 percentage units higher concentration of $\mathrm{CP}$ than the $34 \mathrm{~N}(P=0.001)$ and $67 \mathrm{~N}(P=0.035)$ treatments, respectively, but was not different $(P=0.21)$ from the $101 \mathrm{~N}$ treatment. Forage receiving $101 \mathrm{~N}$ had 0.7 percentage unit higher $(P=0.039) \mathrm{CP}$ concentration than $34 \mathrm{~N}$, but was not different $(P=0.37)$ from the $67 \mathrm{~N}$ treatment.

\subsection{Neutral Detergent Fiber}

Clipping forage to a $10-\mathrm{cm}$ height resulted in a 0.9 percentage-unit increase $(P=0.02)$ in NDF concentration compared with clipping to a $5-\mathrm{cm}$ height (Table 4). A clipping height $\times$ fertilizer source interaction $(P=0.06)$ was observed such that forage amended with PL and clipped to a $10-\mathrm{cm}$ height had 1.0 and 1.7 percentage units higher NDF concentration than forage clipped to a 5 -cm height and amended with CF $(P=0.06)$ and PL ( $P$ $=0.003)$, respectively.

Table 3. Concentration of CP (\%, DM basis) in dallisgrass amended with commercial fertilizer (CF) or poultry litter (PL) at 4 rates of $\mathrm{N}$ application and clipped to a 5- or 10-cm height.

\begin{tabular}{cccccc}
\hline Fertilizer source & \multicolumn{2}{c}{ CF } & \multicolumn{2}{c}{ PL } & Mean \\
\cline { 1 - 5 } N application rate, $\mathrm{kg} / \mathrm{ha}$ & $5 \mathrm{~cm}$ & $10 \mathrm{~cm}$ & $5 \mathrm{~cm}$ & $10 \mathrm{~cm}$ & \\
\hline 34 & 9.8 & 9.2 & 8.7 & 9.0 & $9.2^{\mathrm{a}}$ \\
67 & 10.3 & 9.7 & 9.2 & 9.2 & $9.6^{\mathrm{ab}}$ \\
101 & 10.6 & 10.1 & 9.3 & 9.7 & $9.9^{\mathrm{bc}}$ \\
134 & 10.8 & 10.9 & 9.9 & 9.9 & $10.4^{\mathrm{c}}$ \\
Mean & 10.4 & 10.0 & 9.3 & 9.4 & \\
Fertilizer-source mean & \multicolumn{3}{c}{$10.2^{\mathrm{d}}$} & \multicolumn{3}{c}{$9.4^{\mathrm{e}}$} \\
\hline
\end{tabular}

${ }_{\mathrm{a}, \mathrm{b}, \mathrm{c}}$ Within a column, means without a common superscript differ $(P=0.009$; $\mathrm{SEM}=0.3 ; \mathrm{n}=48){ }^{\mathrm{d}, \mathrm{e}}$ Within a row, means without a common superscript $\operatorname{differ}(P=0.002 ;$ SEM $=0.2 ; \mathrm{n}=96)$.

Table 4. Concentration of NDF (\%, DM basis) in dallisgrass amended with commercial fertilizer (CF) or poultry litter (PL) at 4 rates of $\mathrm{N}$ application and clipped to a 5- or 10-cm height.

\begin{tabular}{ccccccc}
\hline Clipping height & \multicolumn{2}{c}{$5 \mathrm{~cm}$} & \multicolumn{2}{c}{$10 \mathrm{~cm}$} & \multirow{2}{*}{ Mean } \\
\cline { 1 - 5 } N application rate, kg/ha & CF & PL & CF & PL & \\
\hline 34 & 67.1 & 66.3 & 67.3 & 68.7 & 67.4 \\
67 & 66.6 & 66.4 & 67.4 & 66.9 & 66.8 \\
101 & 65.9 & 67.0 & 66.8 & 67.6 & 66.8 \\
134 & 67.1 & 64.5 & 65.9 & 67.8 & 66.3 \\
Mean & $66.7^{\mathrm{a}}$ & $66.0^{\mathrm{a}}$ & $66.8^{\mathrm{ab}}$ & $67.7^{\mathrm{b}}$ & \\
Clipping-height mean & $66.4^{\mathrm{c}}$ & $67.3^{\mathrm{d}}$ & \\
\hline
\end{tabular}

${ }^{\mathrm{a}, \mathrm{b}}$ Within a row, means without a common superscript differ $(P=0.06$; SEM $=1.7 ; \mathrm{n}=48) .{ }^{\mathrm{c}, \mathrm{d}}$ Within a row, means without a common superscript differ $(P=0.02 ; \mathrm{SEM}=1.7 ; \mathrm{n}=96)$. 


\subsection{Acid Detergent Fiber}

Forage clipped to a $10-\mathrm{cm}$ height had 0.8 percentage unit higher $(P=0.002)$ concentration of ADF than forage clipped to a $5-\mathrm{cm}$ height (Table 5). Forage receiving $134 \mathrm{~N}$ had 1.1 and 0.7 percentage units lower ADF concentration than the $34 \mathrm{~N}(P=0.001)$ and $67 \mathrm{~N}(P=0.06)$ treatments, respectively. Forage receiving $101 \mathrm{~N}$ had 0.6 percentage unit lower $(P=0.09)$ ADF concentration than the $34 \mathrm{~N}$ treatment, but was not different from the $67 \mathrm{~N}$ ( $P$ $=0.66)$ or $134 \mathrm{~N}(P=0.13)$ treatments.

\subsection{Acid Detergent Lignin}

Clipping forage to a $5-\mathrm{cm}$ height resulted in a 0.2 percentage-unit increase $(P=0.08)$ in ADL concentration compared with clipping to a $10-\mathrm{cm}$ height (Table 6). A clipping height $\times$ fertilizer source interaction $(P=0.08)$ was observed such that forage amended with $\mathrm{CF}$ and clipped to a 5-cm height had $0.4,0.5$ and 0.4 percentage units higher ADL concentration than PL-amended forage clipped to a 5-cm height $(P=0.04), \mathrm{CF}$-amended forage clipped to a $10-\mathrm{cm}$ height $(P=0.02)$, and PL-amended forage clipped to a $10-\mathrm{cm}$ height $(P=0.04)$, respectively.

Table 5. Concentration of ADF (\%, DM basis) in dallisgrass amended with commercial fertilizer (CF) or poultry litter (PL) at 4 rates of $\mathrm{N}$ application and clipped to a 5- or 10-cm height.

\begin{tabular}{ccccccc}
\hline Clipping height & \multicolumn{2}{c}{$5 \mathrm{~cm}$} & \multicolumn{2}{c}{$10 \mathrm{~cm}$} & \multirow{2}{*}{ Mean } \\
\cline { 1 - 5 } N application rate, kg/ha & CF & PL & CF & PL & \\
\hline 34 & 33.8 & 33.9 & 34.4 & 35.0 & $34.3^{\mathrm{a}}$ \\
67 & 33.8 & 33.7 & 34.1 & 33.8 & $33.9^{\mathrm{ab}}$ \\
101 & 33.0 & 33.7 & 34.0 & 34.1 & $33.7^{\mathrm{bc}}$ \\
134 & 33.2 & 31.8 & 33.6 & 34.1 & $33.2^{\mathrm{c}}$ \\
Mean & 33.5 & 33.3 & 34.0 & 34.3 & \\
Clipping-height mean & $33.4^{\mathrm{d}}$ & \multicolumn{3}{c}{$34.2^{\mathrm{e}}$} \\
\cline { 1 - 4 }
\end{tabular}

a,b,c Within a column, means without a common superscript differ $(P=0.015$; SEM $=0.3 ; \mathrm{n}=48) .{ }^{\mathrm{d}, \mathrm{e}}$ Within a row, means without a common superscript differ $(P=0.002 ; \mathrm{SEM}=0.2 ; \mathrm{n}=96)$.

Table 6. Concentration of ADL (\%, DM basis) in dallisgrass amended with commercial fertilizer (CF) or poultry litter (PL) at 4 rates of $\mathrm{N}$ application and clipped to a 5- or 10-cm height.

\begin{tabular}{ccccccc}
\hline Clipping height & \multicolumn{2}{c}{$5 \mathrm{~cm}$} & \multicolumn{2}{c}{$10 \mathrm{~cm}$} & \multirow{2}{*}{ Mean } \\
\cline { 1 - 4 } N application rate, kg/ha & CF & PL & CF & PL & \\
\hline 34 & 4.2 & 3.9 & 3.7 & 3.8 & 3.9 \\
67 & 4.2 & 3.8 & 3.8 & 3.7 & 3.9 \\
101 & 4.3 & 3.7 & 3.6 & 3.9 & 3.9 \\
134 & 4.2 & 3.8 & 3.9 & 3.8 & 3.9 \\
Mean & $4.2^{\mathrm{a}}$ & $3.8^{\mathrm{b}}$ & $3.7^{\mathrm{b}}$ & $3.8^{\mathrm{b}}$ & \\
Clipping-height mean & \multicolumn{2}{c}{$4.0^{\mathrm{c}}$} & \multicolumn{3}{c}{$3.8^{\mathrm{d}}$} \\
\cline { 1 - 2 }
\end{tabular}

${ }^{\mathrm{a}, \mathrm{b}}$ Within a row, means without a common superscript differ $(P=0.08 ;$ SEM $=0.1 ; \mathrm{n}=48) .{ }^{\mathrm{c}, \mathrm{d}}$ Within a row, means without a common superscript differ $(P=0.08 ; \mathrm{SEM}=0.1 ; \mathrm{n}=96)$.

\subsection{Calcium}

Forage clipped to a $10-\mathrm{cm}$ height had 0.05 percentage unit lower $(P<0.001)$ concentration of $\mathrm{Ca}$ than forage clipped to a $5-\mathrm{cm}$ height (Table 7). There was a 0.03 percentage unit higher $(P=0.003)$ concentration of $\mathrm{Ca}$ in forage amended with $\mathrm{CF}(0.49 \%)$ than PL $(0.46 \%)$, but there were no differences $(P=0.63)$ in forage concentration of $\mathrm{Ca}$ among $\mathrm{N}$ application-rate treatments.

\subsection{Phosphorus}

Forage clipped to a $5-\mathrm{cm}$ height had 0.01 percentage unit higher $(P=0.01)$ concentration of $\mathrm{P}$ than forage clipped to a $10-\mathrm{cm}$ height (Table 8). There was a 0.01 percentage unit higher $(P<0.001)$ concentration of $\mathrm{P}$ in forage amended with PL $(0.18 \%)$ than $\mathrm{CF}(0.17 \%)$, but forage concentrations of $\mathrm{P}$ were not different $(P=0.68)$ among $\mathrm{N}$ application-rate treatments. A clipping height $\times$ fertilizer source interaction $(P=0.06)$ was observed such that forage amended with PL and clipped to a $5-\mathrm{cm}$ height had $0.02,0.03$ and 0.02 percentage unit higher concentration of $\mathrm{P}$ than $\mathrm{CF}$-amended forage clipped to a 5 -cm height $(P<0.001), C F$-amended forage clipped to a

Table 7. Concentration of $\mathrm{Ca}(\%, \mathrm{DM}$ basis) in dallisgrass amended with commercial fertilizer (CF) or poultry litter (PL) at 4 rates of $\mathrm{N}$ application and clipped to a 5- or 10-cm height.

\begin{tabular}{ccccccc}
\hline Clipping height & \multicolumn{2}{c}{$5 \mathrm{~cm}$} & \multicolumn{2}{c}{$10 \mathrm{~cm}$} & \multirow{2}{*}{ Mean } \\
\cline { 1 - 4 } N application rate, kg/ha & CF & PL & CF & PL & \\
\hline 34 & 0.50 & 0.51 & 0.46 & 0.43 & 0.48 \\
67 & 0.52 & 0.50 & 0.46 & 0.44 & 0.48 \\
101 & 0.51 & 0.48 & 0.47 & 0.42 & 0.47 \\
134 & 0.49 & 0.47 & 0.48 & 0.42 & 0.46 \\
Mean & 0.51 & 0.49 & 0.47 & 0.43 & \\
Clipping-height mean & \multicolumn{2}{c}{$0.50^{\mathrm{a}}$} & \multicolumn{2}{c}{$0.45^{\mathrm{b}}$} & \\
\hline
\end{tabular}

${ }^{\mathrm{a}, \mathrm{b}}$ Within a row, means without a common superscript differ $(P<0.001$; $\mathrm{SEM}=0.01 ; \mathrm{n}=96)$.

Table 8. Concentration of $\mathrm{P}(\%, \mathrm{DM}$ basis) in dallisgrass amended with commercial fertilizer (CF) or poultry litter (PL) at 4 rates of $\mathrm{N}$ application and clipped to a 5 - or $10-\mathrm{cm}$ height.

\begin{tabular}{|c|c|c|c|c|c|}
\hline Clipping height & \multicolumn{2}{|c|}{$5 \mathrm{~cm}$} & \multicolumn{2}{|c|}{$10 \mathrm{~cm}$} & \multirow{2}{*}{ Mean } \\
\hline $\mathrm{N}$ application rate, $\mathrm{kg} / \mathrm{ha}$ & $\mathrm{CF}$ & PL & $\mathrm{CF}$ & PL & \\
\hline 34 & 0.18 & 0.18 & 0.17 & 0.17 & 0.18 \\
\hline 67 & 0.17 & 0.19 & 0.16 & 0.17 & 0.17 \\
\hline 101 & 0.16 & 0.19 & 0.16 & 0.17 & 0.17 \\
\hline 134 & 0.16 & 0.18 & 0.17 & 0.18 & 0.17 \\
\hline Mean & $0.17^{\mathrm{ab}}$ & $0.19^{\mathrm{c}}$ & $0.16^{\mathrm{a}}$ & $0.17^{\mathrm{b}}$ & \\
\hline Clipping-height mean & \multicolumn{2}{|c|}{$0.18^{\mathrm{d}}$} & \multicolumn{2}{|c|}{$0.17^{\mathrm{e}}$} & \\
\hline
\end{tabular}

${ }^{\mathrm{a}, \mathrm{b}, \mathrm{c}}$ Within a row, means without a common superscript differ $(P=0.06$; $\mathrm{SEM}=0.01 ; \mathrm{n}=48) .{ }^{\mathrm{d}, \mathrm{e}}$ Within a row, means without a common superscript $\operatorname{differ}(P=0.01 ; \mathrm{SEM}=0.01 ; \mathrm{n}=96)$. 
10-cm height $(P<0.001)$, and PL-amended forage clipped to a $10-\mathrm{cm}$ height $(P=0.002)$, respectively. Also, forage amended with PL and clipped to a $10-\mathrm{cm}$ height had 0.01 percentage unit higher $(P<0.08)$ concentration of $P$ than forage clipped to a $10-\mathrm{cm}$ height and amended with CF.

\subsection{Potassium}

Forage clipped to a $10-\mathrm{cm}$ height had 0.07 percentage unit higher $(P=0.001)$ concentration of $\mathrm{K}$ than forage clipped to a 5-cm height (Table 9). There was a 0.29 percentage unit higher $(P<0.001)$ concentration of $\mathrm{K}$ in forage amended with PL (1.03\%) than CF $(0.74 \%)$, but there were no differences $(P=0.11)$ among $\mathrm{N}$ application-rate treatments in forage concentrations of $\mathrm{K}$. A clipping height $\times$ fertilizer source interaction $(P<0.001)$ was observed such that forage amended with $\mathrm{CF}$ and clipped to a $5-\mathrm{cm}$ height had $0.39,0.18$ and 0.36 percentage unit lower concentration of $\mathrm{K}$ than forage clipped to a 5-cm height and amended with PL $(P<$ $0.001)$, forage clipped to a 10-cm height and amended with CF $(P<0.001)$, and forage clipped to a $10-\mathrm{cm}$ height and amended with PL $(P<0.001)$, respectively. Also, forage amended with PL and clipped to a $5-\mathrm{cm}$ height had 0.21 percentage unit higher $(P<0.001)$ concentration of $\mathrm{K}$ than forage clipped to a $10-\mathrm{cm}$ height and amended with $\mathrm{CF}$, and forage amended with $\mathrm{CF}$ and clipped to a $10-\mathrm{cm}$ height had 0.18 percentage unit lower $(P<0.001)$ concentration of $\mathrm{K}$ than forage clipped to a $10-\mathrm{cm}$ height and amended with PL. A fertilizer source $\times$ $\mathrm{N}$ application rate interaction $(P<0.001)$ was also observed. Forage concentration of $\mathrm{K}$ increased as $\mathrm{N}$ application rate increased in forage amended with PL such that the $34 \mathrm{~N}$ treatment $(0.91 \%)$ had $0.10,0.17$, and 0.20 percentage unit lower concentration of $\mathrm{K}$ than the $67 \mathrm{~N}$ (1.01\%; $P=0.02), 101 \mathrm{~N}(1.08 \% ; P<0.001)$, and $134 \mathrm{~N}$ $(1.11 \% ; P<0.001)$ treatments. Forage amended with PL and $67 \mathrm{~N}$ had 0.10 percentage unit lower $(P=0.04)$ concentration of $\mathrm{K}$ than the $134 \mathrm{~N}$ treatment. In contrast, forage amended with $\mathrm{CF}$ and receiving $34 \mathrm{~N}(0.79 \%)$ had 0.09 percentage unit higher $(P=0.04)$ concentration of $\mathrm{K}$ than the $134 \mathrm{~N}(0.70 \%)$ treatment, but did not differ from the $67 \mathrm{~N}(0.72 \% ; P=0.13)$ and $101 \mathrm{~N}(0.75 \% ; P=0.40)$ treatments.

\subsection{Magnesium}

Clipping forage to a $5-\mathrm{cm}$ height increased $(P<0.001)$ concentration of $\mathrm{Mg}$ over that of forage clipped to a 10-cm height (Table 10). There was a 0.06 percentage unit higher $(P<0.001)$ concentration of $\mathrm{Mg}$ in forage amended with CF $(0.25 \%)$ than PL $(0.19 \%)$, but there were no differences $(P=0.70)$ among fertilizer-rate treatments in forage concentration of $\mathrm{Mg}$. An interaction
Table 9. Concentration of $\mathrm{K}$ (\%, DM basis) in dallisgrass amended with commercial fertilizer (CF) or poultry litter (PL) at 4 rates of $\mathrm{N}$ application and clipped to a 5 - or $10-\mathrm{cm}$ height.

\begin{tabular}{cccccc}
\hline Clipping height & \multicolumn{2}{c}{$5 \mathrm{~cm}$} & \multicolumn{2}{c}{$10 \mathrm{~cm}$} & \multirow{2}{*}{ Mean } \\
\cline { 1 - 5 } N application rate, kg/ha & CF & PL & CF & PL & \\
\hline 34 & 0.69 & 0.93 & 0.89 & 0.89 & 0.85 \\
67 & 0.65 & 1.05 & 0.78 & 0.98 & 0.87 \\
101 & 0.66 & 1.12 & 0.84 & 1.05 & 0.92 \\
134 & 0.59 & 1.08 & 0.81 & 1.13 & 0.90 \\
Mean & $0.65^{\mathrm{a}}$ & $1.04^{\mathrm{b}}$ & $0.83^{\mathrm{c}}$ & $1.01^{\mathrm{b}}$ & \\
Clipping-height mean & \multicolumn{2}{c}{$0.85^{\mathrm{d}}$} & \multicolumn{3}{c}{$0.92^{\mathrm{e}}$} \\
\cline { 1 - 4 }
\end{tabular}

${ }^{\mathrm{a}, \mathrm{b}, \mathrm{c}}$ Within a row, means without a common superscript differ $(P<0.001$ $\mathrm{SEM}=0.02 ; \mathrm{n}=48) .{ }^{\mathrm{d}, \mathrm{e}}$ Within a row, means without a common superscript differ $(P=0.001 ;$ SEM $=0.02 ; \mathrm{n}=96)$.

Table 10. Concentration of $\mathrm{Mg}(\%, \mathrm{DM}$ basis) in dallisgrass amended with commercial fertilizer (CF) or poultry litter (PL) at 4 rates of $\mathrm{N}$ application and clipped to a 5- or 10-cm height.

\begin{tabular}{ccccccc}
\hline Clipping height & \multicolumn{2}{c}{$5 \mathrm{~cm}$} & \multicolumn{2}{c}{$10 \mathrm{~cm}$} & Mea \\
\cline { 1 - 5 } $\begin{array}{c}\text { N application rate, } \\
\mathrm{kg} / \mathrm{ha}\end{array}$ & $\mathrm{CF}$ & $\mathrm{PL}$ & $\mathrm{CF}$ & $\mathrm{PL}$ & $\mathrm{n}$ \\
\hline 34 & 0.25 & 0.22 & 0.21 & 0.18 & 0.22 \\
67 & 0.28 & 0.20 & 0.22 & 0.18 & 0.22 \\
101 & 0.30 & 0.19 & 0.24 & 0.17 & 0.22 \\
134 & 0.28 & 0.19 & 0.25 & 0.17 & 0.22 \\
Mean & $0.27^{\mathrm{a}}$ & $0.20^{\mathrm{b}}$ & $0.23^{\mathrm{c}}$ & $0.17^{\mathrm{d}}$ \\
Clipping-height mean & \multicolumn{2}{c}{$0.24^{\mathrm{e}}$} & \multicolumn{3}{c}{$0.20^{\mathrm{f}}$} \\
\hline
\end{tabular}

a,b,c,d Within a row, means without a common superscript differ $(P=0.06$; SEM $=0.01 ; \mathrm{n}=48) .{ }^{\mathrm{e}, \mathrm{f}}$ Within a row, means without a common superscript differ $(P<0.001 ; \mathrm{SEM}=0.01 ; \mathrm{n}=96)$.

$(P=0.06)$ was observed such that each clipping-height $\times$ fertilizer-source treatment was different $(P<0.001)$ from each other. Also, a fertilizer source $\times \mathrm{N}$ application-rate interaction $(P<0.001)$ was observed. Forage concentration of $\mathrm{Mg}$ increased with increasing $\mathrm{N}$ application rate in forage amended with CF such that $34 \mathrm{~N}(0.23 \%)$ had $0.02,0.04$, and 0.03 percentage unit lower concentration of $\mathrm{Mg}$ than the $67 \mathrm{~N}(0.25 \% ; P=0.02), 101 \mathrm{~N}(0.27 \% ; P$ $<0.001)$, and $134 \mathrm{~N}(0.26 \% ; P<0.001)$ treatments. Forage amended with $\mathrm{CF}$ and $67 \mathrm{~N}$ had 0.02 percentage unit lower $(P=0.09)$ concentration of $\mathrm{Mg}$ than the $101 \mathrm{~N}$ treatment. In contrast, concentration of $\mathrm{Mg}$ decreased with increasing $\mathrm{N}$ application rate in forage amended with PL such that $34 \mathrm{~N}(0.20 \%)$ had 0.02 percentage unit higher concentration of $\mathrm{Mg}$ than the $101 \mathrm{~N}(0.18 \% ; P=$ $0.009)$ and $134 \mathrm{~N}(0.18 \% ; P=0.008)$ treatments.

\subsection{Aluminum}

Clipping forage to a 5-cm height resulted in a 407 $\mathrm{mg} / \mathrm{kg}$ increase $(P<0.001)$ in concentration of Al compared with clipping to a $10-\mathrm{cm}$ height (Table 11). There 
were no differences $(P=0.63)$ in forage concentrations of $\mathrm{Al}$ between fertilizer sources or among $\mathrm{N}$ application-rate treatments $(P=0.49)$.

\subsection{Copper}

Clipping forage to a 5-cm height resulted in a 1.4 $\mathrm{mg} / \mathrm{kg}$ increase $(P=0.03)$ in concentration of $\mathrm{Cu}$ compared with clipping to a $10-\mathrm{cm}$ height (Table 12). There was no difference in forage concentration of $\mathrm{Cu}$ between fertilizer-source $(P=0.17)$ or among $\mathrm{N}$ application-rate treatments $(P=0.38)$; however, a fertilizer source $\times \mathrm{N}$ application-rate interaction $(P=0.02)$ was observed such that forage amended with PL and $101 \mathrm{~N}(9.6 \mathrm{mg} / \mathrm{kg}) \mathrm{had}$ $3.9 \mathrm{mg} / \mathrm{kg}$ higher $(P=0.002)$ concentration of $\mathrm{Cu}$ than forage amended with PL and 34N $(5.7 \mathrm{mg} / \mathrm{kg})$. However, there were no differences $(P=0.15)$ among $\mathrm{N}$ application-rate treatments in concentration of $\mathrm{Cu}$ in $\mathrm{CF}$ amended forages. Also, a clipping height $\times$ fertilizer source $\times \mathrm{N}$ application rate interaction was observed $(P=$ $0.10)$.

\subsection{Iron}

Clipping forage to a $5-\mathrm{cm}$ height resulted in a 273

Table 11. Concentration of $\mathrm{Al}(\mathrm{mg} / \mathrm{kg}$, DM basis) in dallisgrass amended with commercial fertilizer (CF) or poultry litter (PL) at 4 rates of $\mathrm{N}$ application and clipped to a 5- or 10-cm height.

\begin{tabular}{cccccc}
\hline Clipping height & \multicolumn{2}{c}{$5 \mathrm{~cm}$} & \multicolumn{2}{c}{$10 \mathrm{~cm}$} & \multirow{2}{*}{ Mean } \\
\cline { 1 - 5 } N application rate, $\mathrm{kg} / \mathrm{ha}$ & $\mathrm{CF}$ & PL & CF & PL & \\
\hline 34 & 838 & 1,091 & 420 & 295 & 661 \\
67 & 586 & 523 & 302 & 479 & 473 \\
101 & 695 & 799 & 462 & 286 & 561 \\
134 & 728 & 864 & 302 & 322 & 554 \\
Mean & 712 & 819 & 372 & 346 & \\
Clipping-height mean & \multicolumn{3}{c}{$766^{\mathrm{a}}$} & \multicolumn{3}{c}{$359^{\mathrm{b}}$} \\
\hline
\end{tabular}

${ }^{\mathrm{a}, \mathrm{b}}$ Within a row, means without a common superscript differ $(P<0.001$; $\mathrm{SEM}=339 ; \mathrm{n}=96$ ).

Table 12. Concentration of $\mathrm{Cu}(\mathrm{mg} / \mathrm{kg}, \mathrm{DM}$ basis) in dallisgrass amended with commercial fertilizer (CF) or poultry litter (PL) at 4 rates of $\mathrm{N}$ application and clipped to a 5- or 10-cm height.

\begin{tabular}{|c|c|c|c|c|c|}
\hline \multirow{2}{*}{$\begin{array}{c}\text { Clipping height } \\
\mathrm{N} \text { application rate, } \mathrm{kg} / \mathrm{ha}\end{array}$} & \multicolumn{2}{|c|}{$5 \mathrm{~cm}$} & \multicolumn{2}{|c|}{$10 \mathrm{~cm}$} & \multirow{2}{*}{ Mean } \\
\hline & $\mathrm{CF}$ & PL & $\mathrm{CF}$ & PL & \\
\hline 34 & 6.1 & 6.6 & 8.7 & 4.9 & 6.6 \\
\hline 67 & 6.6 & 7.1 & 5.3 & 8.1 & 6.8 \\
\hline 101 & 6.6 & 12.9 & 5.3 & 6.3 & 7.8 \\
\hline 134 & 8.9 & 8.5 & 6.7 & 6.8 & 7.7 \\
\hline Mean & 7.1 & 8.8 & 6.5 & 6.5 & \\
\hline Clipping-height mean & \multicolumn{2}{|c|}{$7.9^{\mathrm{a}}$} & \multicolumn{2}{|c|}{$6.5^{\mathrm{b}}$} & \\
\hline
\end{tabular}

${ }^{\mathrm{a}, \mathrm{b}}$ Within a row, means without a common superscript differ $(P=0.03$; SEM $=0.7 ; \mathrm{n}=96$ ). $\mathrm{mg} / \mathrm{kg}$ increase $(P<0.001)$ in concentration of Fe compared with clipping to a $10-\mathrm{cm}$ height (Table 13). There was no difference in forage Fe concentration between fertilizer-source $(P=0.69)$ or among $\mathrm{N}$ application-rate treatments $(P=0.39)$.

\subsection{Manganese}

Forage clipped to a $5-\mathrm{cm}$ height had $28 \mathrm{mg} / \mathrm{kg}$ higher $(P<0.001)$ concentration of $\mathrm{Mn}$ than forage clipped to a 10 -cm height (Table 14). There was an $18 \mathrm{mg} / \mathrm{kg}$ higher $(P=0.008)$ concentration of $\mathrm{Mn}$ in forage amended with CF $(159 \mathrm{mg} / \mathrm{kg}$ ) than PL (141 mg/kg), but there were no differences $(P=0.17)$ among $\mathrm{N}$ application-rate treatments in forage concentration of $\mathrm{Mn}$. A clipping height $\times$ fertilizer source interaction $(P<0.001)$ was observed such that forage amended with $\mathrm{CF}$ and clipped to a $5-\mathrm{cm}$ height had 47 and $37 \mathrm{mg} / \mathrm{kg}$ lower concentration of $\mathrm{Mn}$ than PL-amended forage clipped to a 5 -cm height $(P<$ $0.001)$ and $C F-a m e n d e d$ forage clipped to a $10-\mathrm{cm}$ height $(P<0.001)$, respectively. Forage amended with PL and clipped to a 10-cm height had 46, 93 and $83 \mathrm{mg} / \mathrm{kg}$ lower concentration of $\mathrm{Mn}$ than $\mathrm{CF}$-amended forage clipped to a 5-cm height $(P<0.001)$, PL-amended forage clipped to a 5-cm height $(P<0.001)$, and $C F$-amended forage clipped to a $10-\mathrm{cm}$ height $\mathrm{CF}(P<0.001)$, respectively.

\subsection{Zinc}

Forage clipped to a $5-\mathrm{cm}$ height had $5.0 \mathrm{mg} / \mathrm{kg}$ higher $(P<0.001)$ concentration of $\mathrm{Zn}$ than forage clipped to a 10-cm height (Table 15). There was no fertilizer source effect $(P=0.21)$ on forage concentration of $\mathrm{Zn}$. However, forage receiving $134 \mathrm{~N}$ had 2.8 and $2.4 \mathrm{mg} / \mathrm{kg}$ higher concentration of $\mathrm{Zn}$ than $34 \mathrm{~N}(P=0.02)$ and $67 \mathrm{~N}(P=$ $0.05)$ forages, respectively. A clipping height $\times$ fertilizer source interaction $(P<0.001)$ was observed such that forage amended with $\mathrm{CF}$ and clipped to a $5-\mathrm{cm}$ height had $4.2 \mathrm{mg} / \mathrm{kg}$ lower $\mathrm{Zn}$ concentration than forage clipped to a 5-cm height and amended with PL $(P<$ $0.001)$. Forage amended with PL and clipped to a $10-\mathrm{cm}$ height had $3.9,8.1$ and $2.1 \mathrm{mg} / \mathrm{kg}$ lower concentration of $\mathrm{Zn}$ than $\mathrm{CF}$-amended forage clipped to a 5-cm height $(P$ $=0.001)$, PL-amended forage clipped to a $5-\mathrm{cm}$ height $(P$ $<0.001$ ), and CF-amended forage clipped to a $10-\mathrm{cm}$ height CF $(P=0.08)$, respectively. Forage amended with $\mathrm{PL}$ and clipped to a $5-\mathrm{cm}$ height had $6.0 \mathrm{mg} / \mathrm{kg}$ higher concentration of $\mathrm{Zn}$ than forage clipped to a $10-\mathrm{cm}$ height and amended with CF $(P<0.001)$.

\section{DISCUSSION}

Information on forage yield is used by the resource manager to establish forage allowance, and for this reason it is an especially important factor influencing graz- 
Table 13. Concentration of Fe ( $\mathrm{mg} / \mathrm{kg}$, DM basis) in dallisgrass amended with commercial fertilizer (CF) or poultry litter (PL) at 4 rates of $\mathrm{N}$ application and clipped to a 5- or 10-cm height.

\begin{tabular}{cccccc}
\hline Clipping height & \multicolumn{2}{c}{$5 \mathrm{~cm}$} & \multicolumn{2}{c}{$10 \mathrm{~cm}$} & \multirow{2}{*}{ Mean } \\
\cline { 1 - 5 } N application rate, $\mathrm{kg} / \mathrm{ha}$ & $\mathrm{CF}$ & PL & CF & PL & \\
\hline 34 & 522 & 770 & 290 & 198 & 445 \\
67 & 362 & 363 & 198 & 294 & 304 \\
101 & 488 & 539 & 346 & 173 & 387 \\
134 & 495 & 568 & 220 & 197 & 370 \\
Mean & 467 & 560 & 264 & 216 & \\
Clipping-height mean & \multicolumn{3}{c}{$513^{\mathrm{a}}$} & \multicolumn{3}{c}{$240^{\mathrm{b}}$} \\
\cline { 1 - 3 }
\end{tabular}

${ }^{a, b}$ Within a row, means without a common superscript differ $(P<0.001$; $\mathrm{SEM}=215 ; \mathrm{n}=96$ ).

ing-animal performance [15]. Also, yield is directly related to sward density, structure and height, all of which have been shown to be key determinants of grazing behavior and voluntary forage intake by cattle $[7,9,10]$. Because of the truncated experimental period utilized in each year of the present study, cumulative production of dallisgrass was somewhat less than more typical seasonal production reported by other investigators [1,16-18]. Also, dallisgrass is best adapted to regions that receive more than $900 \mathrm{~mm}$ of annual rainfall [19], and lack of rainfall may partially explain why forage in the present study did not develop to its full production potential, especially in 2007.

The influence of sward height on ingestive behavior and intake of dallisgrass by cattle has been documented in a number of studies [7-10]. In general, these authors have reported that cattle modify their bite mass, defoliation area and depth of grazing in the forage canopy in response to changes in sward height, forage density, and relative proportions of leaf and stem tissue. Less extensively studied is the resilience of dallisgrass to forage and grazing-animal management practices that result in low stubble heights and significantly reduced photosynthetic leaf area and carbohydrate reserves for production of vegetative regrowth. Clipping dallisgrass to a $5-\mathrm{cm}$ height resulted in an increase of more than $70 \%$ in DM yield over clipping to a 10 -cm height, which is considerably greater than the $11.5 \%$ increase in DM yield reported by Holt and McDaniel [17] for dallisgrass clipped to a $5-\mathrm{cm}$ compared with a $15-\mathrm{cm}$ height. Dallisgrass clipped to a $5-\mathrm{cm}$ height yielded 1239 and $552 \mathrm{~kg} \mathrm{DM} / \mathrm{ha}$ for first and second harvests, respectively, across both years of the study; however, dallisgrass clipped to a $10-\mathrm{cm}$ height yielded only 592 and $455 \mathrm{~kg} \mathrm{DM} / \mathrm{ha}$ for first and second harvests, respectively. Because regrowth DM yield compared favorably between the cuttingheight treatments, cutting primary growth to the lower stubble height evidently did not compromise its regrowth potential compared with that of primary growth clipped
Table 14. Concentration of $\mathrm{Mn}(\mathrm{mg} / \mathrm{kg}$, DM basis) in dallisgrass amended with commercial fertilizer $(\mathrm{CF})$ or poultry litter (PL) at 4 rates of $\mathrm{N}$ application and clipped to a $5-$ or $10-\mathrm{cm}$ height.

\begin{tabular}{cccccc}
\hline Clipping height & \multicolumn{2}{c}{$5 \mathrm{~cm}$} & \multicolumn{2}{c}{$10 \mathrm{~cm}$} & \multirow{2}{*}{ Mean } \\
\cline { 1 - 5 } N application rate, kg/ha & CF & PL & CF & PL & \\
\hline 34 & 168 & 193 & 200 & 87 & 162 \\
67 & 138 & 197 & 166 & 100 & 150 \\
101 & 137 & 205 & 169 & 84 & 149 \\
134 & 121 & 156 & 178 & 109 & 141 \\
Mean & $141^{\mathrm{a}}$ & $188^{\mathrm{b}}$ & $178^{\mathrm{b}}$ & $95^{\mathrm{c}}$ & \\
Clipping-height mean & \multicolumn{3}{c}{$164^{\mathrm{d}}$} & \multicolumn{3}{c}{$136^{\mathrm{c}}$} \\
\hline
\end{tabular}

a,b,c Within a row, means without a common superscript differ $(P<0.001$; SEM $=33 ; \mathrm{n}=48) .{ }^{\mathrm{d}, \mathrm{e}}$ Within a row, means without a common superscript $\operatorname{differ}(P<0.001 ; \mathrm{SEM}=32 ; \mathrm{n}=96)$.

to the higher stubble height. Watson and Ward [20] reported higher daily and total seasonal regrowth yields with reductions in clipping height, and suggested that dallisgrass could tolerate clipping to stubble heights as low as $2.5 \mathrm{~cm}$ as long as at least $10 \%$ of tillers were left intact.

Yield of dallisgrass DM increased as a result of increasing $\mathrm{N}$ application from $34 \mathrm{~N}$ and $67 \mathrm{~N}$ to $134 \mathrm{~N}$. Similarly, Robinson et al. [18] reported an increase in dallisgrass DM yield from $5330 \mathrm{~kg}$ to $15,340 \mathrm{~kg} / \mathrm{ha}$ when $\mathrm{N}$ fertilization rate was increased from 0 to $896 \mathrm{~kg} / \mathrm{ha}$. Likewise, Pizarro [1] reported increases in DM production from dallisgrass ranging from 2400 to $9000 \mathrm{~kg} / \mathrm{ha}$ over a 5-yr period with increasing $\mathrm{N}$ fertilization from 0 to $500 \mathrm{~kg} / \mathrm{ha}$ in increments of $100 \mathrm{~kg} / \mathrm{ha}$. Jones and Watson [21] reported increases in yield of dallisgrass-bermudagrass pasture with increasing rates of fertilization with $\mathrm{N}$, but no yield response to fertilization with either $\mathrm{P}$ or $\mathrm{K}$ alone in the absence of added N. Brown and Rouse [22] also reported increases in yield of dallisgrass DM with increasing rates of $\mathrm{N}$ fertilization in a greenhouse study with white clover-dallisgrass cultures.

Forage protein is an important source of $\mathrm{N}$ for ruminal microorganisms, and an important goal of forage management is to derive as much of the $\mathrm{N}$ requirement as possible from forage in order to limit or eliminate the need for supplementation. The range of forage concentrations of CP observed in the present study was similar to that observed by Venuto et al. [19], who reported concentrations of $\mathrm{CP}$ in dallisgrass of $9.8 \%$ to $11 \%$, and lower than that observed by Baréa et al. [23], who reported a wider range of concentrations of $\mathrm{CP}$ in dallisgrass of $10.7 \%$ to $18.6 \%$. Using prediction equations of Linn and Marten [24], dallisgrass in the present study would be expected to have approximately $87 \%$ the relative feed value (RFV) of a mature, medium-quality alfalfa 
Table 15. Concentration of $\mathrm{Zn}$ (mg/kg, DM basis) in dallisgrass amended with commercial fertilizer (CF) or poultry litter (PL) at 4 rates of $\mathrm{N}$ application and clipped to a 5- or 10-cm height.

\begin{tabular}{cccccc}
\hline Clipping height & \multicolumn{2}{c}{$5 \mathrm{~cm}$} & \multicolumn{2}{c}{$10 \mathrm{~cm}$} & \multirow{2}{*}{ Mean } \\
\cline { 1 - 5 } N application rate, $\mathrm{kg} / \mathrm{ha}$ & $\mathrm{CF}$ & PL & CF & PL & \\
\hline 34 & 24.0 & 29.7 & 27.6 & 21.8 & $25.8^{\mathrm{d}}$ \\
67 & 26.1 & 28.6 & 24.1 & 25.7 & $26.2^{\mathrm{d}}$ \\
101 & 27.6 & 35.6 & 23.7 & 22.8 & $27.5^{\mathrm{ef}}$ \\
134 & 31.7 & 32.2 & 26.7 & 23.5 & $28.6^{\mathrm{f}}$ \\
Mean & $27.4^{\mathrm{a}}$ & $31.6^{\mathrm{b}}$ & $25.6^{\mathrm{a}}$ & $23.5^{\mathrm{c}}$ & \\
Clipping-height mean & $29.5^{\mathrm{g}}$ & \multicolumn{2}{c}{$24.5^{\mathrm{h}}$} \\
\hline
\end{tabular}

a,b,c Within a row, means without a common superscript differ $(P<0.001$; $\mathrm{SEM}=1.5 ; \mathrm{n}=48){ }^{\mathrm{d}, \mathrm{e}, \mathrm{f}}$ Within a column, means without a common superscript differ $(P=0.08 ; \mathrm{SEM}=1.5 ; \mathrm{n}=48) .{ }^{\mathrm{g}, \mathrm{h}}$ Within a row, means without a common superscript differ $(P<0.001 ; \mathrm{SEM}=1.3 ; \mathrm{n}=96)$.

hay; i.e., $\sim 60 \% \mathrm{TDN}$. Values for $\mathrm{CP}$ concentration and RFV of dallisgrass in the present study may be compared with those required by a growing beef steer of $340 \mathrm{~kg}$ liveweight (8.5\% CP and 60\% TDN, DM basis) from a daily DM intake of $9.2 \mathrm{~kg}$ to achieve an ADG of $0.80 \mathrm{~kg}$ [25].

There was no difference in forage concentration of CP between the two clipping-height treatments. Nutritive quality varies within the forage canopy such that stems and younger leaves in the upper canopy are of higher quality than stems and older or dead leaves in the lower canopy [26,27]. Results of the present study are interpreted to mean that quality of available forage in the lower canopy would not be expected to differ between grazing management intensities that produce variable stubble heights below $10 \mathrm{~cm}$.

Forage concentration of $\mathrm{CP}$ was greater for $\mathrm{CF}$ than PL treatments. Wood et al. [28] observed no difference between $\mathrm{N}$-source treatments in $\mathrm{CP}$ concentration of "Tifton 44" Bermudagrass amended with either CF or PL; however, there was an increase in $\mathrm{CP}$ concentration with increasing rates of fertilization with N. Similarly, forage concentration of $\mathrm{CP}$ increased in both CF- and PLamended dallisgrass with increasing rates of $\mathrm{N}$ application in the present study, in agreement with other published reports of dallisgrass response to fertilization with $\mathrm{N}[3,29,30]$. According to Gunter et al. [31], dallisgrass typically has higher $\mathrm{CP}$ concentration and in vivo DM digestibility than bermudagrass (Cynodon dactylon), and supports greater liveweight gain in stocker cattle.

Concentration of NDF is negatively correlated with voluntary intake of forage DM [32]. The NDF fraction represents the recalcitrant fibrous components (primarily cellulose, hemicellulose and lignin fractions) of the plant cell wall that are negatively correlated with forage density and in turn form the physical basis of its utility as a predictor of DMI [33]. On average, concentrations of NDF in dallisgrass in the present study were slightly lower than those observed by Venuto et al. [19], who reported concentrations of $70.7 \%$ for dallisgrass grown in Texas and $69.5 \%$ for dallisgrass grown in Louisiana. However, concentrations of NDF in the present study were very similar to those observed by Acosta et al. [29], who reported a mean value of $67.6 \%$ for dallisgrass in the spring in Buenos Aires, Argentina. Clipping at 10-cm height resulted in a slightly higher ( $<1$ percentage unit) NDF concentration than clipping at $5-\mathrm{cm}$ height, but this difference would not be expected to have a measurable effect on voluntary DM intake by a free-grazing ruminant animal.

Forage concentration of ADF is negatively correlated with its digestibility in vivo, and comprises the lignin, cutin, cellulose, indigestible $\mathrm{N}$ and silica fractions of the plant cell wall [34]. In the present study, concentration of ADF was slightly higher ( $<1$ percentage unit) in dallisgrass clipped to a $10-\mathrm{cm}$ than $5-\mathrm{cm}$ height, but this increase would not be expected to have a measurable effect on digestibility in vivo. Values for ADF were slightly below those observed by Ayala Torales et al. [30], who reported concentrations of $\mathrm{ADF}$ in dallisgrass ranging from $35.2 \%$ to $39.5 \%$, and intermediate to those observed by Acosta et al. [29], who reported values ranging from $31.3 \%$ in the winter to $39.7 \%$ in the summer in Argentina. Higher rates of fertilization resulted in lower concentrations of ADF in dallisgrass in the present study, in contrast to findings of Wood et al. [28] who reported increased concentration of crude fiber with increasing rates of $\mathrm{N}$ fertilization in "Tifton 44" Bermudagrass.

Plant cell wall availability to herbivores is limited by different factors, one of the most important being lignin [34]. Concentration of lignin increases and digestibility of plant cell-wall constituents and total plant DM decreases with advancing forage maturity [35]. Clipping to a $5-\mathrm{cm}$ height resulted in a higher concentration of ADL than that in forage clipped to a $10-\mathrm{cm}$ height, which can be explained by the fact that younger leaves and stems are located in the upper stratum of the forage canopy, and therefore lignin concentration is expected to be higher in the lower stratum where the more mature steams and leaves are located. However, it is unlikely that the small difference in concentration of lignin between clippingheight treatments in the present study would be sufficient to result in a measurable difference in cell-wall or wholeplant DM digestibility in vivo.

Forage concentration of minerals is dependent upon numerous factors, including plant development stage, climatic conditions, soil characteristics and fertilization regime [36]. Among these, soil fertilization can be manipulated by the resource manager in order to provide different types and quantities of nutrients for plants; generally, it is more economical to fertilize plants in order to 
achieve maximum growth, and then supplement as necessary to meet requirements for animal production [36].

Forage concentrations of $\mathrm{Ca}$ in the present study were, on average, less than half of those reported by Brown and Rouse [22] for dallisgrass cultivated in a greenhouse in association with white clover. Concentrations of $\mathrm{Ca}$ were higher in dallisgrass amended with CF than PL in the present study, in contrast to the study by Wood et al. [28] in which Ca concentration in "Tifton 44" Bermudagrass amended with PL was higher than in unfertilized forage or forage amended with ammonium nitrate. Results of the present study are similar to those of Robinson et al. [18], who reported Ca concentration values for dallisgrass of $0.39 \%$ to $0.48 \%$.

Phosphorus is arguably the single mineral element that is most commonly deficient for meeting animal requirements from grazed forages. Because of its importance in various metabolic processes in animals, notably energy metabolism, dietary P deficiency can very likely result in a deficiency of energy [36]. In the present study, concentration of $\mathrm{P}$ was higher in dallisgrass amended with $\mathrm{PL}$ than CF, in contrast to the study by Wood et al. [28] in which there was no difference in concentrations of $\mathrm{P}$ between "Tifton 44" Bermudagrass amended with CF or PL. Also, concentration of $\mathrm{P}$ was higher in dallisgrass clipped to a $5-\mathrm{cm}$ than $10-\mathrm{cm}$ height. In general, values were lower than the range of values $(0.27 \%$ to $0.29 \%)$ reported by Robinson et al. [18].

Concentration of $\mathrm{K}$ was higher in forage amended with PL than CF, similar to results reported by Wood et al. [28] for "Tifton 44" Bermudagrass; however, there was an increase in $\mathrm{K}$ accumulation with increasing rate of $\mathrm{N}$ fertilization with PL and a decrease in K concentration with increasing rate of $\mathrm{N}$ fertilization with $\mathrm{CF}$ in their study, in contrast to the present study in which rate of $\mathrm{N}$ application had no effect on $\mathrm{K}$ concentration in dallisgrass. Forages normally contain sufficient $\mathrm{K}$ for meeting grazing animals' requirements; however, high $(>2.5 \%)$ forage concentration of $\mathrm{K}$ may interfere with bioavailability of $\mathrm{Mg}$ [36]. Concentration of $\mathrm{K}$ in dallisgrass averaged $0.89 \%$ in the present study, well below the threshold at which it can potentially be problematic for $\mathrm{Mg}$ absorption, and less than half of that in the study by Robinson et al. [18], who reported concentrations of $\mathrm{K}$ in dallisgrass of $2.04 \%$ to $2.24 \%$. Potassium concentrations in this study, on average, were similar to those reported by Brown and Rouse [22] for dallisgrass grown in a greenhouse in association with white clover. Concentration of $\mathrm{Mg}$ was higher in dallisgrass amended with $\mathrm{CF}$ than PL, and increased with increasing rate of $\mathrm{N}$ application from CF, in agreement with Robinson et al. [18] who reported an increase from $0.19 \%$ to $0.36 \% \mathrm{Mg}$ when $\mathrm{N}$ application rate was increased from 0 to $896 \mathrm{~kg} / \mathrm{ha}$.

Utilization of PL as a fertilizer source has an advan- tage over synthetic fertilizers of providing trace minerals that are important for plant and animal nutrition. However, it is important to recognize the potential for toxicity to livestock that may result from repeated land-application of PL and possible accumulation of certain trace minerals in soil and grazed forage. Franzluebbers et al. [37] reported 4.1 and $7.8 \mathrm{mg} / \mathrm{kg}$ greater concentrations of extractable-soil $\mathrm{Zn}$ and $\mathrm{Cu}$, respectively, in the upper $15-\mathrm{cm}$ horizon of a Piedmont soil at the end of a $5-\mathrm{yr}$ period of land-application of PL at a rate of $196 \mathrm{~kg}$ $\mathrm{N} \cdot \mathrm{ha}^{-1} \cdot \mathrm{yr}^{-1}$. Gascho and Hubbard [38] reported a fourand five-fold increase in concentrations of $\mathrm{Cu}$ and $\mathrm{Zn}$, respectively, in the surface of a Tifton soil in the Coastal Plain of Georgia following land-application of PL at a rate of $2812 \mathrm{~kg} \mathrm{~N} / \mathrm{ha}$ over a 5 -yr period.

Iron concentration in forages grown in the US typically meets or exceeds animal dietary requirements [36]. Concentration of $\mathrm{Fe}$ in dallisgrass in the present study was well above the dietary requirement $(50 \mathrm{mg} / \mathrm{kg} \mathrm{DM})$ for beef cattle [25], and was higher in forage clipped to a 5- than 10-cm height. Some trace elements are not required or may be required in small amounts, and if ingested and absorbed in excessive amounts can be toxic to cattle. Aluminum is one such trace mineral for which the maximum tolerable concentration (MTC) for beef cattle is $1000 \mathrm{mg} / \mathrm{kg}$ DM [25]. Dallisgrass clipped to a $5-\mathrm{cm}$ height had a higher concentration of Al than forage clipped to a 10-cm height and, with the exception of forage amended with PL at the $34 \mathrm{~N}$ application rate had concentrations of Al that were below the MTC for beef cattle.

Suboptimal $\mathrm{Cu}$ status in ruminants may be caused by low forage concentration of $\mathrm{Cu}$, high concentration of a $\mathrm{Cu}$ antagonist such as $\mathrm{Fe}$, or a combination of both [36]. Concentration of $\mathrm{Cu}$ in the present study was higher for dallisgrass clipped to a 5- than 10-cm height, and on average was below the concentration required $(10 \mathrm{mg} / \mathrm{kg}$ DM) by beef cattle [25]. Concentration of Mn, which is normally higher in forage than required by the animal [36], was higher in dallisgrass amended with CF than PL in the present study. Zinc and $\mathrm{Cu}$ are often deficient in warm-season grasses, and normally are the most limiting trace minerals in both warm-season and cool-season forages [36]. Deficiencies of trace minerals in grazed forage require supplementation in order to meet animal requirements for maximum performance and optimal health. Zinc is one such trace mineral for which deficiency in forages is not uncommon in the US [36]. Concentration of $\mathrm{Zn}$ in dallisgrass was below that required (30 mg/kg DM) by beef cattle [25], and was not different between clipping-height and fertilizer-source treatments or among $\mathrm{N}$ application-rate treatments in the present study. 


\section{IMPLICATIONS}

Results indicate that dallisgrass can withstand defoliation to a $5-\mathrm{cm}$ stubble height, thereby increasing DM yield compared with defoliation to a $10-\mathrm{cm}$ stubble height, without compromising forage quality or capacity for regrowth. Also, dallisgrass amended with PL or CF was comparable in productivity and nutritive quality as determined by laboratory analysis. Dallisgrass amended with PL had higher concentrations of $\mathrm{P}$ and $\mathrm{K}$ than $\mathrm{CF}$-amended dallisgrass, but trace-mineral profiles were not markedly different between dallisgrass amended with PL or CF. Results are interpreted to mean that poultry litter may offer potential as a safe, cost-effective alternative to commercial fertilizer for supporting productivity and nutritive quality of dallisgrass on Black Belt soils.

\section{REFERENCES}

[1] Pizarro, E.A. (2000) Potencial forrajero del género Paspalum. Pasturas Tropicales, 22, 38-46.

[2] Chase, A. (1929) The North American species of Paspalum. Contributions from the United States National Herbarium, 28, 310.

[3] Holt, E.C. (1956) Dallisgrass. Texas Agricultural Experimental Station Bulletin, 829, 1-14.

[4] AASS (1996) Alabama agricultural statistics service. Montgomery.

[5] Davies, L.J. and Forde, B.J. (1991) Comparative responses of three subtropical grasses to combined frost and prolonged chilling treatments simulating a New Zealand winter. New Zealand Journal of Agricultural Research, 34, 249-256. doi:10.1080/00288233.1991.10417661

[6] Evers, G.W. and Burson, B.L. (2004) Dallisgrass and other Paspalum species. In: Moser, L.E. et al., Eds., Warm-Season (C4) Grasses, (pp 681-713), Madison, Agronomy Monographs, 45.

[7] Lippke, H. (1981) Intake, digestibility, and sward characteristics of bermudagrass-dallisgrass pastures. Texas Agricultural Experiment Station Progress Report, 3826, 173-174.

[8] Ungar, E.D., Genizi, A. and Detriment, M.W. (1991) Bite dimensions and herbage intake by cattle grazing short hand-constructed swards. Agronomy Journal, 83, 973-978. doi:10.2134/agronj1991.00021962008300060010x

[9] Laca, E.L., Ungar, E.D., Seligman, N. and Demment, M.W. (1992) Effect of sward height and bulk density on bite dimensions of cattle grazing homogeneous swards. Grass and Forage Science, 47, 91-102. doi:10.1111/j.1365-2494.1992.tb02251.x

[10] Flores, E.R., Laca, E.A., Griggs, T.C. and Demment, M.W. (1993) Sward height and vertical morphological differentiation determine cattle bite dimensions. Agronomy Journal, 85, 527-532. doi:10.2134/agronj1993.00021962008500030001x

[11] AOAC (1995) Official methods of analysis. 16th Edition,
Association of Official Analytical Chemists, Washington DC.

[12] Van Soest, P.J., Robertson, J.B. and Lewis, B.A. (1991) Methods for dietary fiber, neutral detergent fiber, and nonstarch polysaccharides in relation to animal nutrition. Journal of Dairy Science, 74, 3583-3597. doi:10.3168/jds.S0022-0302(91)78551-2

[13] Olsen, S.R. and Sommers, L.E. (1982) Phosphorus. In: Page, A.L., Miller, R.H. and Keeney, D.R., Eds., Methods of Soil Analysis. Part 2: Chemical and Microbiological Properties, American Society of Agronomy, Inc., Madison, 403-427.

[14] SAS Institute (2004) SAS/STAT user's guide. Version 9.1. SAS Institute Inc., Cary.

[15] Minson, D.J. and Wilson, J.R. (1994) Prediction of intake as an element of forage quality. In: Fahey Jr., G.C., et al., Eds., Forage Quality, Evaluation, and Utilization, American Society of Agronomy, Inc., Madison, 533-563.

[16] Lovvorn, R.L. (1944) The effects of fertilization, species competition, and cutting treatments on the behavior of dallisgrass, Paspalum dilatatum Poir., and carpetgrass, Axonopus affinis, Chase. Agronomy Journal, 36, 590-600. doi:10.2134/agronj1944.00021962003600070007x

[17] Holt, E.C. and McDaniel, J.C. (1963) Influence of clipping on yield, regrowth, and root development of dallisgrass, Paspalum dilatatum Poir., and kleingrass, Panicum coloratum L. Agronomy Journal, 55, 561-564. doi:10.2134/agronj1963.00021962005500060018x

[18] Robinson, D.L., Wheat, K.G., Hubbert, N.L., Henderson, M.S. and Savoy Jr., H.J. (1988) Dallisgrass yield, quality and nitrogen recovery response to nitrogen and phosphorus fertilizers. Communications in Soil Science and Plant Analysis, 19, 529-542. doi:10.1080/00103628809367957

[19] Venuto, B.C., Burson, B.L., Hussey, M.A., Redfearn, D.D., Wyatt, W.E. and Brown, L.P. (2003) Forage yield, nutritive value, and grazing tolerance of dallisgrass biotypes. Crop Science, 43, 295-301. doi: $10.2135 /$ cropsci2003.0295

[20] Watson, V.W. and Ward, C.Y. (1970) Influence of intact tillers and height of cut on regrowth and carbohydrate reserves of dallisgrass (Paspalum dilatatum Poir.). Crop Science, 10, 474-476. doi:10.2135/cropsci1970.0011183X001000050004x

[21] Jones, W.F. and Watson, V.H. (1991) Applied phosphorus and potassium effects on yield of dallisgrass-Bermudagrass pastures. Journal of Plant Nutrition, 14, 585-597. doi:10.1080/01904169109364226

[22] Brown, J.M. and Rouse, R.D. (1953) Fertilizer effects on botanical and chemical composition of white clover-dallisgrass associations grown on Sumter clay. Agronomy Journal, 45, 279-282. doi:10.2134/agronj1953.00021962004500070002x

[23] Baréa, K., Scheffer-Basso, S.M., Dall'Agnol, M. and de Oliveira, B.N. (2007) Management of Paspalum dilatatum Poir. biotype Virasoro. 1. Production, chemical composition and persistence. Revista Brasileira de Zootecnia, 36, 992-999. doi:10.1590/S1516-35982007000500002 
[24] Linn, J.G. and Martin, N.P. (1989) Forage quality tests and interpretation. University of Minnesota Extension Service Publication, St. Paul.

[25] NRC (1996) Nutrient requirements of beef cattle. 7th Edition, National Academy Press, Washington DC.

[26] Brisibe, E.A., Umoren, U.E., Brisibe, F., Magalhäes, P.M., Ferreira, J.F.S., Luthria, D., Wuh, X. and Prior, R.L. (2009) Nutritional characterization and antioxidant capacity of different tissues of Artemisia annua L. Food Chemistry, 115, 1240-1246. doi:10.1016/j.foodchem.2009.01.033

[27] Nordheim-Viken, H., Volden, H. and Jørgensen, M. (2009) Effects of maturity stage, temperature and photoperiod on growth and nutritive value of timothy (Phleum pratense L.). Animal Feed Science and Technology, 152, 204-218. doi:10.1016/j.anifeedsci.2009.04.012

[28] Wood, C.W., Torbert, H.A. and Delaney, D.P. (1993) Poultry litter as a fertilizer for bermudagrass: Effects on yield and quality. Journal of Sustainable Agriculture, 3, 21-36. doi:10.1300/J064v03n02 05

[29] Acosta, G., Deregibusand, V.A. and Hammar, R. (1996) Inclusión de pasto miel (Paspalum dilatatum, Poir) en pasturas. 2. Efecto sobre el valor nutritivo. Revista Argentina de Producción Animal, 16, 157-167.

[30] Ayala Torales, A.T., Acosta, G.L., Deregibus, V.A. and Moauro, P.M. (2000)Effects of grazing frequency on the production, nutritive value, herbage utilization, and structure of a Paspalum dilatatum sward. New Zealand Journal of Agricultural Research, 43, 467-472. doi:10.1080/00288233.2000.9513443
[31] Gunter, S.A., Beck, P.A., Hutchison, S. and Phillips, J.M. (2005) Effects of stocking and nitrogen fertilization rates on steers grazing dallisgrass-dominated pasture. Journal of Animal Science, 83, 2235-2242.

[32] Paterson, J.A., Belyea, R.L., Bowman, J.P., Kerley, M.S. and Williams, J.E. (1994) The impact of forage quality and supplementation regimen on ruminant animal intake and performance. In: Fahey Jr., G.C., et al., Eds., Forage Quality, Evaluation, and Utilization, American Society of Agronomy, Inc., Madison, 59-114.

[33] Mertens, D.R. (1987) Predicting intake and digestibility using mathematical models of ruminal function. Journal of Animal Science, 64, 1548-1558.

[34] Van Soest, P.J. (1994) Nutritional ecology of the ruminant. 2nd Edition, Cornell University Press, Ithaca.

[35] Jung, H.G. and Fahey Jr., G.C. (1983) Nutritional implications of phenolic monomers and lignin: A review. Journal of Animal Science, 57, 206-219.

[36] Greene, L.W. (2000) Designing mineral supplementation of forage programs for beef cattle. Journal of Animal Science, 77, 1-9.

[37] Franzluebbers, A.J., Wilkinson, S.R. and Stuedemann, J.A. (2004) Bermudagrass management in the southern piedmont USA: VIII. Soil $\mathrm{pH}$ and nutrient cations. Agronomy Journal, 96, 1390-1399. doi:10.2134/agronj2004.1390

[38] Gascho, G.J. and Hubbard, R.K. (2006) Long-term impact of broiler litter on chemical properties of a Coastal Plain soil. Journal of Soil and Water Conservation, 61, 65-74. 